\title{
BENDERA MACAN ALI \\ KOLEKSI MUSEUM TEKSTIL JAKARTA
}

\author{
Tawalinuddin Haris
}

\begin{abstract}
The Textile Museum of Jakarta in Tanah Abang preserves a ragged animal calligraphy embroidered in indigo banner framed in white silk cloth of the Cirebon Sultanate made in 1797. The old bunting has three pictures of "Ali" Tiger painted in Arabic letters, a double-edged Sword of Zulfakar, four magical square boxes decorated with Arabic inscription, and Arabic letters quoted from the Quran on five-cornered stars. The paper describes the significance of the regalia: it does not only function as the symbol of sovereignty of the Cirebon Sultanate, but it also has a magical power to protect the kingdom.
\end{abstract}

\section{Keywords}

Insignia of Tiger Ali, Qur'anic Verses, Sword of Zulfakar, the Magical Square.

\section{PENDAHULUAN}

Bendera adalah sehelai kain yang memiliki ukuran tertentu serta memakai warna dan lambang atau lukisan yang mempunyai arti sesuai dengan tujuannya. Selain itu bendera merupakan simbol kedaulatan, kekuasaan atau hak hukum dari suatu negara. Meskipun pemakaian bendera sebagai simbol suatu negara atau bangsa dikaitkan dengan munculnya nasionalisme, pemakaian simbol semacam itu dapat dilacak keberadaannya jauh ke belakang pada permulaan sejarah. Pemakaian bendera oleh bangsa-bangsa di dunia sekarang ini kemungkinan berasal dari simbol suku-suku tertentu yang berbentuk burung atau binatang. Simbol-simbol itu ditempatkan di ujung tongkat yang selalu dibawa dalam peperangan. Diduga simbol-simbol seperti itu sudah dipergunakan oleh orangorang Mesir, Yunani, dan Persia Kuno. Pada mulanya bendera tanpa memakai gambar, dan baru pada permulaan abad ke-4 Kaisar Romawi, Constantine, memakai bendera dari sutra yang disulam dengan tanda salib. Di Inggris, simbol gereja (salib) pada bendera sudah ada pada masa St. Augustiny, sedangkan pemakaian lambang heraldik pada bendera baru berkembang pada masa kemudian. Contoh klasik bendera dengan lambang heraldik adalah bendera kerajaan Inggris Raya (Great Britain). Pada bendera tersebut terdapat 
gambar singa emas Inggris, singa merah Skotlandia, dan harpa Irlandia yang merupakan simbol kesatuan kerajaan di bawah seorang raja (Collier's Encyclopedia Vol. 8, 110).

Selain itu, bendera dengan motif-motif atau gambar-gambar tertentu dipakai sebagai lambang identitas suatu institusi, partai politik, dan organisasi kemasyarakatan, termasuk persaudaraan-persaudaraan sufi. Sebagai contoh, bendera-bendera dengan tiang berbentuk ekor yak (sapi liar di Afrika) yang disebut thugs dikenal luas di kalangan para sufi dan kelompok-kelompok yang berkaitan dengan sufi seperti solidaritassolidaritas futuwwah. Konon ketika salah seorang istri Sultan Mamluk meninggal dunia pada tahun 1467, tandu jenazahnya ditutupi dengan bendera merah dari para darwish Ahmad Al-Badawi untuk mendapatkan rahmatnya (Schimmel 1997, 74).

Bendera juga sering dikaitkan dengan peristiwa kematian. Pengibaran bendera setengah tiang adalah tanda berkabung atas meninggalnya seorang tokoh tertentu, sedangkan pemasangan bendera kuning atau putih di suatu tempat menandakan bahwa di sekitar tempat itu ada orang yang meninggal. Di Iran, untuk menandai kuburan seorang yang saleh di hutan belantara, orang-orang menempatkan bendera berwarna-warni di puncak tumpukan batu-batunya. Demikian pula dalam pertemuan majelis Syi'ah pada bulan Muharram, bendera-bendera dalam berbagai warna ditempatkan di sebuah sudut (tempat) tertentu untuk mengingatkan para peserta pertemuan akan bendera-bendera yang pernah dibawa oleh pahlawan Abbas dalam perang Karbala. Bendera-bendera ini kemudian disentuh oleh para peserta untuk mendapatkan barakahnya. Akan tetapi, yang paling penting dalam tradisi muslim ialah konsep "liwaa al-hamd", yaitu panji-panji pujian yang akan dibawa oleh Nabi Muhammad pada Hari Kiamat. Konon orang-orang beriman akan berkumpul di Padang Mahsyar di bawah bendera berwarna hijau yang akan menjadi perantara menuju keselamatan abadi (Schimmel 1997, 75). Warna hijau sering dikaitkan sebagai warna 'Islamik", karena dalam Alquran dinyatakan bahwa surga berwarna hijau (Alquran Surat al-Rahman, 64) dan pakaian ahli surga dari sutra berwarna hijau (Alquran Surat al-Kahfi, 31).

Ada sejumlah istilah atau nama yang sering dikaitkan dengan bendera, yakni panjipanji, umbul-umbul, tunggul, dan rontek. Meskipun maksudnya sama, secara kontekstual terkadang dibedakan. Panji-panji biasanya dipakai untuk menyebut bendera lambang institusi, partai politik, organisasi sosial kemasyarakatan, atau kesatuan dalam angkatan perang; bentuknya segi empat; warnanya bermacam-macam disertai dengan gambar lambang institusi atau organisasi yang bersangkutan. Panji-panji dalam bahasa Inggris indentik dengan banner, sedangkan sebutan atau istilah bendera secara umum adalah flag. Tunggul adalah istilah atau sebutan untuk bendera yang sesungguhnya sering dijumpai dalam sastra lama dan sekarang sudah jarang dipergunakan, misalnya bendera pusaka keraton Yogyakarta, Kanjeng Kiyai Tunggul Wulung. Selain itu, panji-panji sering dipakai untuk menyebut bendara yang dibawa oleh pasukan di medan perang. Istilah umbulumbul berasal dari bahasa Jawa untuk menyebut bendera yang bentuknya memanjang 
mengikuti tiang tempat ia diikatkan, sedangkan rontek adalah bendera berukuran kecil yang diikatkan pada tombak. Ada nama lain yang sering dikaitkan dengan bendera karena memiliki fungsi yang sama sebagai lambang atau simbol dari berbagai lembaga, partai politik atau organisasi kemasyarakatan, yaitu vandel. Di dalam Kamus Bahasa Indonesia (KBI) dijelaskan bahwa vandel adalah sepotong kain dengan bentuk dan warna tertentu, tergantung pada tongkat yang dibubuhi gambar (lukisan) lambang dan tulisan semboyan dari suatu perkumpulan atau kesatuan (pelajar, mahasiswa, angkatan perang, olah raga), sekolah, akademi, uiniversitas, organisasi kemasyarakatan, atau partai politik. Bentuk vandel ada yang segitiga, segiempat, atau bagian atasnya setengah lingkaran. Kalau bendera diikatkan pada tongkat (tiang), vandel digantung saja. Di samping itu, pada setiap Hari Raya Galungan atau Kuningan di Bali, umat Hindu biasanya memasang bendera yang diikatkan pada sebatang pohon bambu, yang disebut penjor. Bentuknya hampir sama dengan umbul-umbul, memanjang mengikuti tiangnya, biasanya dipasang di kiri-kanan jalan yang menuju pura atau di halaman pura.

\section{BENDERA MACAN ALI KOLEKSI MUSEUM TEKSTIL}

Di Museum Tekstil, Tanah Abang, Jakarta, tersimpan selembar bendera tua dari Kasultanan Cirebon. Menurut dokumen Museum Tekstil, bendera ini hadiah atau pemberian dari Kanjeng Gusti Putri Mangkunegara ke-VII pada tahun 1976 dan sebagai koleksi museum terdaftar dengan nomor inventaris 017. Bagaimana asal mula bendera ini sampai di tangan keluarga keraton Mangkunegaran belum diperoleh penjelasannya. Bendera ini terbuat dari kain katun berwarna biru tua (indigo), yang pada bagian tepiannya di beri lis (bingkai) dari kain sutra berwarna putih, berukuran $310 \mathrm{~cm}$ x $196 \mathrm{~cm}$, dan berkondisi sangat rapuh sehingga hanya duplikatnya yang sering dipajang di ruang pamer. Pada bendera itu terdapat tiga buah lukisan (gambar) macan yang disamarkan (distilir) dengan tulisan Arab, pedang bermata dua, empat buah kotak segi empat yang bertuliskan huruf Arab, bintang bersudut lima dan inskripsi Arab yang dikutip dari kitab suci Alquran.

Pada sisi atas terdapat tulisan Arab berbunyi "Qulhuwal laahu ahad, Allahushshomad, lam yalid walam yuulad, walam yakullahu' kufuuwan ahad". Kalimat ini merupakan ayat Alquran Surat112(Al-Ikhlas). Pada sisibawah terdapat tulisan yang sama (Arab) berbunyi: "Laa tudrikul abshaa wahuwa yudriku huwal abshaar wahuwal lathifu khabir". Kalimat ini juga dikutip dari kitab suci Alquran Surat 6: 103 (Al-An'am). Setelah dibandingkan dengan teks aslinya dalam kitab suci Alquran ternyata pada kalimat di atas terdapat kesalahan dalam mengutip kalimat maupun dalam penulisan. Kata "tudrikul" (تد ركل) seharusnya

\footnotetext{
${ }^{1}$ Setelah dibandingkan dengan teks aslinya dalam kitab suci Alquran ternyata ada kesalahan dalam

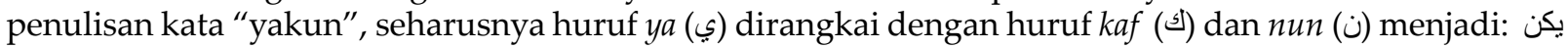
karena kata ini berasal dari akar kata kana (كان (ك) berubah menjadi: يكو ن (yakūnu) (fiil mudhorik), karena di depannya ada lam (لم) sebagai bentuk negasi, maka huruf wau-nya hilang.
} 
"tudrikuhu" (تدركه), dengan huruf kaf (ك) (ك) yang seharusnya dirangkai dengan ha (ح), bukan dengan huruf wau (و); kata "al abshaa" (الابصا) seharusnya "al abshaaru" (الا بصا ر), kurang huruf $r a(ر)$; kata "yudriku" (يد ر كو)" seharusnya tertulis "yudrikul" (يد ركل) karena kata "huwa" (هو (هبير (ه) di depan sesungguhnya tidak ada dalam teks aslinya. Kata "latifu khabir"

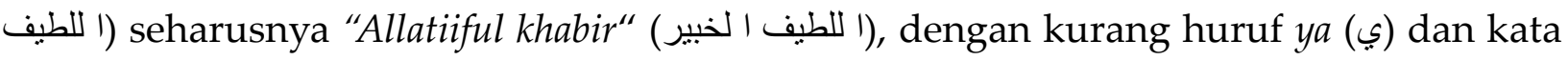
"khabir" (خبير) seharusnya ditulis dengan menambahkan huruf-huruf alif dan lam (' dan J). Dengan demikian ayat Qur'an di atas seharusnya berbunyi, "La tudrukuhul abshaaru

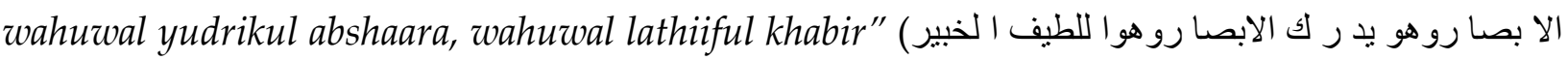
(لا تد ركه yang artinya 'Dia tidak dapat dicapai oleh penglihatan mata, sedang Dia dapat melihat segala yang kelihatan; dan Dialah Yang Mahahalus lagi Maha Mengetahui'.

Di sisi kiri terdapat tulisan yang sama berbunyi: نصرمن الله وفتح قريب وبشر المؤمنين (Nashrum minallah, wafathun qorib, wabashshiril mukminin). Kalimat tersebut adalah kutipan dan penggalan dari Alquran Surat 61: 13 (Ash-Shaff) yang artinya "Pertolongan dari Allah dan kemenangan sudah dekat dan berikan kabar gembira kepada orang-orang mukmin". Di sisi kanan terdapat tulisan berbunyi "Bismillahirrahmaanirrohim" (Dengan nama Allah Yang Maha Pengasih dan Maha Penyayang).

Di tengah-tengah bendera agak ke kanan terdapat gambar pedang bermata dua, yang dalam literatur Islam dikenal sebagai pedang Zulfaqar (Zwemer 1931, 109-21). Di antara kedua mata pedang terdapat huruf-huruf Arab (dari kanan ke kiri): alif (I), ha (ح), jim (ج), zai (j), dal (د), ba (ب), wau (و) dan jim (ج). Huruf-huruf ini memiliki nilai numerik 15374263 , dan angka-angka tersebut ditafsirkan oleh Achjadi sebagai angka tahun 1776 Masehi yang dikaitkan dengan tahun pembuatan bendera (Bennet 2005, 41-285). Di depan (sebelah kiri) pedang terdapat gambar hewan (macan) dalam posisi melompat membelakangi pedang dan digambarkan dengan teknik penyamaran atau stilisasi. Dalam seni rupa Cirebon motif seperti ini dikenal dengan Macan Ali². Ekor macan dibentuk dari huruf lam alif ( $\left({ }^{\prime}\right)$ sehingga berbunyi $l \bar{a}$ dan di dalam lingkaran huruf yang membentuk ekor macan terdapat kalimat "basmallah" (Bismillaahirrohmaannirrohim). Pada garis leher dan paha terdapat huruf lam (ل) yang dirangkai dengan ha (ه) (dua kali) sehingga berbunyi

\footnotetext{
${ }^{2}$ Nama Ali yang ditambahkan di belakang kata macan sesungguhnya tidak ada hubungannya dengan tokoh Ali bin Abi Tholib, sepupu sekaligus menantu Nabi Muhammad saw. Ali bin Abi Tholib yang nama aslinya Haydara (Haydar) sejak masa awal Islam dipuji-puji sebagai sebagai "Singa Tuhan" karena keberaniannya. Beliau dijuluki dengan banyak nama yang menunjukkan sifat-sifat kesingaannya (keberaniannya), seperti Ghandanfar atau As-aa'dullah yang berarti 'Singa Allah'. Di wilayah Persia disebut Alisyr, sedangkan di wilayah yang berada di bawah Turki Osmaniyah disebut Aslan Ali, yang artinya Singa Ali. Sebagai keluarga terdekat Rasulullah, Ali diberi julukan Saa'dullah (Singa Allah) karena keberaniannya dalam peperangan melawan kaum kafir (Schimmel 1997, 64). Dalam Babad Cirebon, nama Ali dalam konsep Macan Ali, dihubungkan dengan kata (a'la) terdiri atas huruf-huruf: ain, lam, dan alif yang berarti 'tinggi', atau dengan kata: عل يا (ulyā), yang terdiri atas huruf-huruf ain, lam, ya, dan alif, yang artinya luhung atau luhur, tinggi, agung atau mulia (Wildan 2002, 48-9). Dengan demikian Macan Ala atau Macan Ulya artinya 'macan tinggi, luhur, luhung, atau mulia'. Menurut hemat penulis, penamaan itu mungkin karena figur Macan Ali atau Macan Ala ini dibentuk dari huruf-huruf Arab

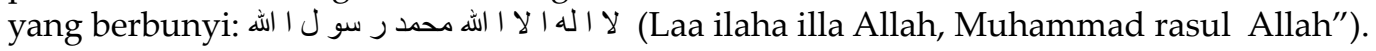


lahu lahu (له له), kaki belakang dibentuk dari huruf-huruf yang berbunyi Allah rasū (الهـ الهو), paha dibentuk dari huruf alif dan lam alif sehingga berbunyi illā (ال ال ال Leher dan kaki depan kanan dibentuk dari huruf-huruf berbunyi Muhammaddarrasūu (محمدر سو), dan kaki depan kiri dibentuk dari huruf-huruf berbunyi Allāh, Allāh (الهَ I الله I). Meskipun masih ada huruf yang belum dapat diidentifikasi, jika direkonstruksi, seluruh tubuh Macan Ali dibentuk الله محمد ر سو ل الله) dari huruf-huruf yang berbunyi Lā ilāha illa Allāh, Muhammadarrasūlullah I \ال لا ע), yang artinya: Tidak ada Tuhan selain Allah, Muhammad utusan Allah.

Di atas gambar Macan Ali (antara kepala dan ekor) ada tulisan berbunyi ya Muhammad (يامحمد); di bawahnya ada huruf-huruf yang ditulis terbalik sehingga diperlukan bantuan cermin untuk membacanya. Tulisan ini berbunyi Allāh (اله) dan Muhammad (محد). Di depan Macan Ali ada gambar bintang bersudut lima yang di dalamnya terdapat tulisan Arab berbunyi Allāh (لآل).

Di atas dan di bawah pedang Zulfakar terdapat gambar Macan Ali yang berukuran lebih kecil, diapit motif geometris segi empat yang berhimpitan dengan bentuk belah ketupat. Pada sudut-sudut segi empat dan belah ketupat ditempatkan segi empat atau belah ketupat yang berukuran kecil sehingga seluruhnya ada 9 buah segi empat yang ditempatkan secara konsentris. Pada bagian terluar ada 7 buah dan di dalamnya 2 buah. Di dalam segi empat yang di tengah terdapat tulisan pendek berbunyi Huwa Allāh (هو (ه) atau bisa juga dibaca Allāh Huwa (الشهو) dan huruf ha(ه). Kalimat tersebut sesungguhnya adalah kalimat zikir atau nama-nama yang mengacu pada nama Allah sehingga tergolong ke dalam huruf-huruf magis (sylable magic). Pada keempat sudut segi empat di luarnya terdapat huruf-huruf ba (ب), wau (و), dal (د) dan ha (ح) sehingga membentuk sebuah kata buduh (بود ح). Di dalam segi empat yang paling luar yang jumlahnya tujuh buah terdapat angka atau bilangan Arab, kecuali angka bilangan lima ( $\bullet$ ). Menurut hemat penulis, ketidakhadiran bilangan lima dalam kotak-kotak itu karena sudah digantikan fungsinya oleh huruf $h a(\tau)$ yang memiliki nilai numerik lima. Memperhatikan jumlah segi empat yang berjumlah 9 buah, formasi penempatannya dalam satu kesatuan dan huruf-huruf serta bilangan yang ditempatkan di dalamnya, gambar-gambar seperti ini mengingatkan pada gambar yang dikenal sebagai "magic square" (Zwemer 1935, 217-2; Shaw 1973, 7) atau segi empat bertuah (segi empat magis). Taylor (1935, 161-5) menyebutnya sebagai cap amulet atau seal of the Amulet yang dalam bahasa Arab disebut wafak atau rajahan dalam bahasa Jawa.

Macan Ali yang ditempatkan di antara kedua segi empat bertuah digambarkan hampir sama, dengan posisi tubuh sedang melompat dan muka menoleh ke kiri sehingga berhadapan dengan pengamat. Namun karena ukurannya agak kecil tidak semua huruf yang membentuk tubuh hewan tersebut dapat diidentifikasi dan dibaca. Yang jelas ekor dan garis punggungnya dibentuk dari huruf yang sama, yaitu huruf lam alif, sehingga berbunyi $l \bar{a}(\gamma)$. 


\section{PEMBAHASAN}

Telah dipaparkan di atas bahwa gambar atau motif Macan Ali disamarkan dalam tulisan Arab berbunyi Lā ilāha illa Allāh, Muhammaddar rasūlullah atau Kalimat Syahadah. Di Keraton Kasepuhan, relief Macan Ali dipahatkan pada dinding tembok bangunan Pamburatan, sedangkan dalam bentuk ukiran lepas ditempatkan pada Bangsal Pringgondani dan di dalam ruangan Masjid Kanoman, Cirebon. Kemudian masih ada sejumlah ukiran kayu Macan Ali yang tersimpan di Museum Keraton Kasepuhan dan Kanoman. Di samping itu gambar atau lukisan Macan Ali ditemukan dalam naskah Babad Talaga, Cirebon dan Majalengka, koleksi Perpustakaan Universitas Leiden, Belanda (Ekadjati 1989), bahkan gambar Macan Ali ditemukan dalam sebuah kitab Alquran kuno dari tahun 1856, koleksi Museum Geusan Ulun, Sumedang (Gallop 2005, 171).

Seperti halnya pada bendera Kasultan Cirebon, figur-figur Macan Ali itu divisualisasikan dengan teknik yang sama, yaitu stilisasi (penyamaran) dalam tulisan Arab berbunyi Lā ilāha illa Allāh, Muhammaddar rasūlullah (لااله الا الله محمد رسول), sehingga sebagai karya seni tergolong ke dalam kaligrafi hewan (animal calligrahpy). Jika di Persia (Iran) kalimat-kalimat yang mengacu kepada pengagungan Sayidina Ali dibentuk dalam wujud singa, dalam kesenian Cirebon kalimat Syahadah disusun membentuk figur Macan Ali. Boleh jadi lukisan, ukiran atau konsep "Macan Ali" merupakan hasil ubah suai dan adaptasi pengaruh budaya Persia dengan kondisi lokal (setempat), mengingat agama Islam dibawa ke Indonesia pada periode awalnya tidak langsung dari Arab, melainkan melalui Iran atau India. Karena dibentuk dari kalimat Lā ilāha illa Allah, Muhammad Rasūlullah, motif ini (Macan Ali) dapat dipandang sebagai personifikasi kalimat Syahadah atau kalimah Tauhid, yang divisualkan bukan hewan (macan) tetapi kalimat Syahadah itu sendiri. Oleh karena itu tidak dipandang sebagai sesuatu yang melanggar hukum Islam, jika ukiran Macan Ali digantung pada dinding di dalam masjid atau gambar Macan Ali ditempatkan dalam kitab suci Alquran.

Membaca kalimat Syahadah adalah rukun Islam yang pertama. Kalimat Syahadah adalah pembatas antara daerah kekufuran dan keimanan. Kalimat itu pulalah yang menjadi pintu gerbang masuknya seseorang dari daerah kafir ke daerah iman karena dengan mengucap kalimat Syahadah status seseorang berubah dari non-muslim menjadi muslim. Dengan demikian kalimat Syahadah identik dengan "simbol Islam". Oleh karena itu kehadiran gambar atau lukisan Macan Ali pada bendera kasultanan Cirebon mungkin dimaksudkan sebagai lambang atau identitas Cirebon sebagai "kerajaan Islam", yaitu kerajaan atau negara yang menegakkan dan menyebarkan kalimat Syahadah. Kesimpulan ini didukung pula oleh indikator-indikator lain pada bendera itu.

Telah disinggung di atas bahwa teks-teks yang tertera pada bendera Macan Ali adalah kalimat basmallah, ayat-ayat Alquran Surat 6 (Al-An'am: 103), Surat 69 (AshShaf: 13), dan Surat 112 (Al-Ikhlas). Formula basmala disebut juga tasmiaya, yang artinya melafalkan nama-nama Allah (Mahmood 1985, 76-7). Di dalam kitab suci Alquran, 
kalimat basmalah ditempatkan pada permulaan setiap surat, kecuali pada Surat 9 (AtTaubah) atau Al-Barā'at. Oleh karena itu para ulama bersilang pendapat apakah formula basmala itu merupakan permulaan dari suatu surat atau hanya sebagai pembatas antara surat yang satu dengan lainnya dan sebagai doa saja. Selain itu formula basmala secara meluas digunakan pula dalam komposisi azimat (talisman) dan dianggap sebagai "sihr halal" atau magis yang sah menurut hukum. Dikatakan bahwa kalimat basmala dituliskan pada paha Nabi Adam, pada sayap Malaikat Jibril, pada cap Nabi Sulaiman dan pada lidah Yesus (Mahmood 1985, 76-77). Rasulullah pernah bersabda: الرحمنالرحيم فهو أ قطع كل أمرذب با لا يبد أ فيه بسم الله (kullu amrin dzibālin lā yabda'u fihi bismillahirrohmaanirrohim fahuwa aqtho), yang artinya setiap perkara yang baik, kalau tidak dimulai dengan membaca bismillahirrahmaanirrahim, maka pekerjaann itu kurang sempurna ${ }^{3}$. Dua di antara ayat-ayat Alquran yang tertera pada bendera Macan Ali, yakni Surat Al-Ikhlas, dan Surat AshShaf: 13) termasuk atau digolongkan sebagai ayat-ayat proteksi atau "al-hifz", yaitu ayat-ayat yang dapat memberikan perlindungan melawan kejahatan sehingga sering dituliskan atau dipakai sebagai azimat (Taylor 1935, 161-5; Zwemer 1935, 20722; Shaw 1973, 7). Bahkan menurut Schimmel (1990, 83-4), Surat Ash-Shaf (61): 13 merupakan salah satu dari ayat-ayat dalam Alquran yang sering dikutip untuk "tujuan apotropaic" (apotropaic purpose), di samping ayat Kursi atau Al-Baqarah: 256. Mungkin karena adanya pemahaman seperti itu, ayat-ayat Alquran ini dikutip dan kemudian dituliskan pada bendera Kasultanan Cirebon. Ketika bendera ini berkibar ditiup angin seolah-olah membaca basmallah, membaca kalimat syahadah dan melafalkan ayat-ayat Alquran karena semua makhluk sesungguhnya diciptakan untuk memuji Tuhan dan bertasbih menurut caranya masing-masing. Ketika bendera itu dibawa ke medan perang diharapkan Allah swt memberikan perlindungan dan memberikan kemenangan kepada pasukan yang membawanya.

Nama lain dari Surat Ikhlas adalah "An-Najat" yang artinya keselamatan dunia dan akhirat atau "As-Shomad", yang artinya tumpuan harapan atau minta pertolongan, Allah tempat tujuan semua makhluk untuk dapat menanggulangi segala kesulitan. Menurut Mohammad Abduh, ayat ini menegaskan bahwa hanya Allah yang menjadi satu-satunya tumpuan. Dalam kitab Durratun Nashihin, yang ditulis oleh Usman bin Hasan bin Ahmad Syakir al-Khaubawi ada penjelasan bahwa Surat Al-Ikhlas tertulis pada empat sayap malaikat, yaitu Malaikat Jibril, Mikail, Izrail, dan Isyrofil serta pada dahi empat sahabat Nabi yaitu Abu Bakar, Umar, Usman, dan Ali (Ramadlan 1987, 1119-28). Malaikat Jibril, Mikail, Izrail, dan Isyrofil disebut juga Malaikat Muqaarrobin, yaitu malaikat yang dekat dengan manusia karena sering turun ke dunia, sedangkan Abu Bakar, Umar, Usman, dan Ali adalah Khalifah ar-Rosyidin dan termasuk di antara sepuluh sahabat yang terkemuka yang dijamin masuk surga oleh Nabi Muhammad saw. Keempat sahabat nabi itu dipandang

\footnotetext{
${ }^{3}$ Periksa Badrie 1984: 5.
} 
sebagai tokoh yang suci dan namanya selalu disebut-sebut dalam setiap khotbah Jumat di seluruh Dunia Islam, kecuali penganut paham Syiah. Oleh karena itu, ada anggapan bahwa menulis namanya pada benda atau bangunan dipandang akan menambah kesaktian (kesucian) benda atau bangunan yang bersangkutan.

Sebagai lambang identitas, bendera atau panji-panji dibawa dalam setiap peperangan. Pada zaman Rasulullah pembawa bendera selalu ditempatkan pada barisan terdepan dalam suatu peperangan. Gambaran seperti itu ditemukan dalam sejarah Islam, baik di masa Nabi Muhammad maupun pada masa khalifah sesudahnya. Dalam setiap peperangan yang dilakukan Rasulullah melawan orang-orang kafir ditunjuk seorang pembawa bendera. Salah seorang di antaranya adalah Ali bin Abi Tholib. Gambaran seperti itu kita jumpai juga dalam sejarah Cirebon. Dalam Babad Tanah Sunda yang dialihaksarakan oleh Pangeran Sulaeman Sulendraningrat, dikisahkan bahwa ketika Cirebon menyerang Raja Galuh dengan bantuan pasukan Demak, pasukan Cirebon di bawah komando Pangeran Cakrabuwana memasang umbul-umbul dan membawa bendera bergambar Macan Ali bertuliskan kaligrafi Arab (Wildan 2002, 56). Jika kisah itu benar, kehadiran Macan Ali sudah ada sejak Sunan Gunung Jati menjadi penguasa di Cirebon, sehingga ada kemungkinan bendera Macan Ali koleksi Museum Tekstil meniru bendera yang sudah ada.

Duplikat bendera Macan Ali yang lain masih tersimpan di Keraton Kacerbonan, yang pada salah satu sisinya terdapat gambar Macan Ali yang disamarkan dengan kalimat Lā ilāha illah Allah, Muhammad Rasuulullah. Di bawahnya terdapat angka 1797 dan tulisan huruf latin berbunyi Kesultanan Ketjirebonan, menggunakan sistem ejaan yang belum disempurnakan. Pada sisi yang lain terdapat sulaman tulisan Arab berbunyi Lā ilāha illa Allah, Muhammad Rasuulullah. Bendera itu dibuat dari kain linen berwarna hijau, sedangkan gambar Macan Ali dan inskripsinya disulam dengan benang berwarna kuning $^{4}$. Kecuali sebagai simbol Islam, kalimat Syahadah dipandang sebagai kalimat yang mengandung daya magis dan merupakan senjata yang ampuh untuk mengusir setan. Seseorang yang sudah mengikrarkannya dan melaksanakan segala konsekuensinya akan selalu dalam perlindungan Allah swt.

Selain pada bendera Macan Ali koleksi Museum Tekstil, Surat Al-Ikhlas dan Surat Ash-Shaf: 13 tertulis pula pada bendera kerajaan Aceh Darussalam yang dirampas oleh Belanda pada tahun 1814 (Juynboll 1873, 325-40), dan pada bendera asal Banten, koleksi Museum Nasional ${ }^{5}$. Bahkan gambar macan pada bendera kerajaan Kelantan (Malaysia) disamarkan dengan kalimat surat Ash-Shaf: 13, Nasrum minallāhi wafathun qarīb, wabasysyirin mukminin (Anonim 1917, 1-10; Al-Ahmadi 1988, 43). Lembaga Riset

\footnotetext{
${ }^{4}$ Periksa juga gambar Sulendraningrat 1978, 17.

${ }^{5}$ Sebagai koleksi Museum Nasional, artefak ini tercatat dengan nomor inventaris 5602 (Periksa Mardiana 2002, 61).
} 
Pesantren Luhur Islam, Jawa Timur dalam penelitiannya berjudul Sejarah dan Da'wah Islamiyah Sunan Giri menyatakan bahwa ketika pasukan Demak menyerang Majapahit di bawah pimpinan Syeh Ja'far Shodiq (Sunan Kudus), mereka membawa bendera yang bertuliskan kalimat Lä ilāha illa Allah, Muhammadur rasuulullah, Nashrumninallah wafathun qorib (Lembaga Riset Pesantren Luhur Islam 1974, 102). Demikian juga Iqbal (2006: 127), dalam disertasinya menyatakan bahwa ketika pasukan Cirebon menyerang pasukan Portugis yang dibantu pasukan Demak di bawah komando Fatahillah pada tahun 1527, pasukan Cirebon membawa panji-panji bertuliskan kalimah basmallah, surat Al-Ikhlas, dan surat Al-Fath. Juga terdapat sebuah inisial dari nama Muhammad saw dan Fatimah as, gambar seekor singa Babar dan pedang Imam Ali yang terkenal dengan julukan Zulfakar sebagai simbol kekuatan dan keberanian Amirul Mukminin as dan gambar dua ekor singa lainnya sebagai simbol Imam Hasan dan Imam Husain as. Gambaran yang diberikan oleh Iqbal itu sangat mirip dengan bendera Macan Ali seperti dipaparkan di atas. Seberapa jauh tingkat kesahihan hasil penelitian itu perlu dikaji lebih jauh karena selain belum didukung oleh bukti, sumber-sumber yang dipergunakan sebagai acuannya juga tidak jelas.

Motif bintang sesungguhnya sudah dikenal sejak khalifah Umar bin Khattab, bahkan pada masa Nabi Muhammad terdapat pasukan perang yang memiliki bendera bergambar bulan sabit dan bintang. Oleh karena itu bulan sabit sering dipandang sebagai simbol Islam atau simbol dakwah Islam meskipun penggambaran bulan sabit pada beberapa bangunan baru ditemukan sebelum munculnya Dinasti Osmaniyah di Turki dan tidak pernah muncul pada abad-abad permulaan Islam (Arnold 1928, 155). Di Jawa Timur motif bintang bersudut delapan dihubungkan dengan penggambaran matahari yang disebut Surya Majapahit. Motif seperti ini dipahat pada candi, nisan kubur ataupun pada bangunan masjid, yang menurut Montana (1983: 723) berfungsi sebagai simbol atau lambang legalitas dan legitimasi Majapahit. Dalam konteks bangunan candi atau makam, mungkin motif bintang bersudut delapan ada kaitannya dengan Surya Majapahit karena motif seperti itu ditemukan pada candi-candi yang berasal dari masa Majapahit, misalnya pada Candi Panataran, Candi Sawentar dan Candi Ngrimbi. Demikian juga pada makam, motif bintang bersudut delapan ditemukan pada beberapa nisan kubur di kompleks makam Sultan Demak, makam Sunan Bonang, dan makam Troloyo, Trowulan, Mojokerto. Di Troloyo, motif ini ditemukan pada kelompok Makam Tujuh atau disebut juga Makam Pangeran Surya. Pada batu nisannya terdapat motif bulatan (medalion) yang dikelilingi oleh tonjolan-tonjolan runcing berjumlah 8 atau 9 yang ditafsirkan sebagai bentuk matahari atau surya. Pada bangunan masjid motif bintang bersudut delapan (matahari) ditemukan di atas lengkungan mihrab Masjid Agung Demak dan di sebelah kanan mihrab Masjid Agung Surakarta. Dari segi bentuk, motif ini boleh jadi merupakan kelanjutan dari motif Surya Majapahit namun dari segi maknanya tentunya telah terjadi pengislaman makna. Matahari oleh kaum sufi dipandang sebagai simbol Tuhan karena 
matahari merupakan sumber dari segala cahaya. Pandangan tersebut didasarkan pada Surat An-Nur (Surat 24: 35) Allahu nurussamawati wal ardhi (الله نور السمو ت والأرض), artinya: Allah adalah sumber cahaya langit dan bumi. Bahkan dalam sebuah hadistnya Nabi Muhammad bersabda: Akulah matahari dan sahabat-sahabatku adalah seperti bintang". Kata bintang dalam hadist tersebut diartikan sebagai "petunjuk" atau "tauladan" bagi mereka yang hidup setelah matahari tenggelam (Schimmel 1996, 50), sebab para sahabat nabi merupakan tauladan bagi umat Islam setelah Nabi Muhammad wafat. Dalam Alquran Surat Al-Mulk $(67,5)$, bintang diibaratkan sebagai alat untuk melempar setan. Allah berfirman: وجعلنهار رجوما للثيطين (.......waja'alnaahaa rujuuman lilsysyayaathiini) artinya: .....dan Kami jadikan bintang-bintang itu sebagai alat untuk pelempar setan. Oleh karena itu maka dalam konteks bendera Macan Ali, bintang bersudut lima dapat juga ditafsirkan sebagai simbol penolak setan.

Menurut sebuah sumber pedang, Zulfakar adalah pedang yang diberikan kepada Nabi Muhammad oleh Malaikat Jibril kemudian diwariskan kepada sepupunya, Ali bin Abi Tholib untuk memotong kepala Marhab, pahlawan Yahudi dalam Perang Khaibar. Dengan pedang itu pula Ali bin Abi Tholib memenangkan pertempuran-pertempuran terbesarnya dengan gagah berani. Menurut E. Mittwoch, pedang itu sebenarnya milik seorang kafir bernama Munabbih bin al- Hajjaj, sedangkan nama pedangnya dihubungkan dengan ungkapan Saif Mufaqqar yang artinya 'pedang bertakik'. Dalam Hyat-ul Kuloob, sumber Persia mengenai kehidupan Nabi Muhammad saw, dijelaskan bahwa Zulfaqar adalah salah satu di antara empat pedang yang dimiliki Nabi Muhammad yaitu Zulfaqar, Aun, Mejzin, dan Rasoon. Di kemudian hari, nama Zulfakar sering diberikan pada pedang seorang pelindung atau setiap alat yang tajam (termasuk lidah tajam seorang penyair) untuk mengungkapkan pencapaian tertinggi dalam mengalahkan musuh (Schimmel 1996, 73). Meskipun bentuknya tidak sama, pedang Zulfakar dikenal di berbagai belahan dunia Islam, mulai dari Maroko sampai Cina dan Indonesia 6 . Selain pada bendera Kasultanan Cirebon Koleksi Museum Tekstil, gambar pedang bermata dua ditemukan juga pada bendera asal Banten koleksi Museum Nasional dan bendera keraton Yogyakarta Hadiningrat, Kiyai Tunggul Wulung dan Kiyai Pare Anom (Tirtakoesoema 1932, 42-3; Bennet 2005, 50). Bahkan gambar pedang pada bendera kerajaan Aceh yang dirampas oleh Belanda dari tahun 1840 diberi nama Zulfakar meskipun mata pedangnya tidak bercabang dua. Penamaan itu didasarkan pada inskripsi huruf Arab yang tertera pada bendera tersebut berbunyi لا فتح الا علي لا سيف الا ذا لفقر (Lā fattah illā Ali, lā saifa illā dzulfakar), yang artinya "Tiada kemenangan kecuali Ali dan tiada pedang kecuali kecuali zulfakar". Dengan mengacu kepada tulisan pada bendera itu, Juynboll menduga ada kemungkinan bahwa

\footnotetext{
${ }_{6}^{6}$ Almarhum Haji Mas Agung, seorang pengusaha keturunan Cina memiliki duplikat pedang Zulfakar, ujungnya bertakik dan bentuknya mirip dengan gambar pedang Nabi Muhammad yang direproduksi di Peking dan fotonya dimuat dalam artikel S.M. Zwemer, "The Sword of Muhammad and Ali", dalam The Moslem World, vol. XXI. 1931, 109-21.
} 
pemilik bendera tersebut adalah orang-orang Syiah moderat (Juynboll 1873, 329-30). Menurut Schimmel (1996: 73), teks-teks serupa sering dituliskan pada baju zirah, dari pelindung dada hingga kaki, dari pelindung kepala hingga tameng, dimaksudkan untuk memberikan kekuatan istimewa pada benda-benda yang bersangkutan.

Telah dijelaskan di atas bahwa pada bendera kesultanan Cirebon koleksi Museum Tekstil terdapat segi empat bertuah atau magic square. Sesuai dengan namanya, ada kemungkinan gambar itu pun dianggap mengandung kekuatan magis sehingga ditempatkan pada bendera Magic square konon dibuat di Cina lebih dari 4.000 tahun yang lalu oleh Kaisar Cina, Yu, berdasarkan tanda-tanda yang dilihatnya pada punggung, kaki, dan ekor kura-kura ketika berlayar di Sungai Kuning (Shaw 1973, 43-4). Tanda-tanda itu diterjemahkan dalam bentuk bilangan (angka-angka) yang ditempatkan dalam 9 kotak segi empat, disusun dalam formasi berjajar tiga. Pada kotak yang di tengah ditempatkan angka 5 yang dalam numerik Cina adalah 'bilangan manusia sempurna' (number of man perfected). Di samping itu, bilangan (angka) 5 dipandang sebagai representasi Tuhan (Shang-ti) dan merupakan kekuatan kosmik yang universal dan penguasa lima jenis kebahagian yaitu umur panjang, kekayaan, kesehatan, kecintaan, dan kematian secara alami (Shaw 1973: 43-4). Di Semenanjung Melayu, segi empat bertuah versi Cina dipergunakan sebagai sarana tolak bala (talisman) dalam ritual sakral masyarakat Cina dan ritual persaudaraan orang-orang Melayu seperti Masyarakat Bendera Merah Putih atau yang berafiliasi dengannya. Sebaliknya, segi empat bertuah versi Arab yang dikenal sebagai segel atau skema Al-Gazali (al-muthallath lil Ghazali) masih digunakan di seluruh Nusantara. Dinamakan demikian karena segi empat bertuah ini dipopulerkan oleh Imam Al-Ghazali (1058-1111 Masehi), yang dikenal sebagai pencipta Ilm Al-Huruf (Macdonald 1993, 770). Dikatakan bahwa Al-Ghazali mengembangkan formula tersebut setelah mendapatkan ilham dengan mengombinasikan huruf-huruf: s (kaf), $ه(h a), ى$ (ya) , ع (ain), w (sin), ق (qaf) dan huruf-huruf: ه (ha), م (mim), ع (ain), w (sin), ق (qaf yang merupakan permulaan Alquran Surat 19 (Surat Maryam) dan Surat 42 (Surat Asysyūara). Di kalangan orang Melayu (termasuk Indonesia), segi empat bertuah disebut juga wafak atau rajahan dituliskan pada kertas atau kain yang dipakai sebagai tolak bala (talisman), azimat (amulet) atau sebagai sarana penyembuhan. Bahkan, sampai dengan awal abad ke-20 di wilayah Priangan, kertas-kertas yang bertuliskan wafak dicelupkan ke dalam air sebelum digunakan untuk mandi pada hari Rabu Pungkasan (Rabu penghabisan) di bulan Syafar atau mandi Syafar (Pijper 1984, 156-9).

Selain itu di dalam segi empat bertuah bendera Macan Ali terdapat huruf-huruf magis (sylable magic) yang dapat dibaca dengan dua cara yaitu huwa allah (Dia Allah) atau allah huwa (Allah Dia), ha dan sebuah kata yang terbentuk dari huruf-huruf: ب (ba), و (wau), $د$ (dal) dan $ح$ (ha), sehingga berbunyi: بو دح (buduh). Kata buduh dihubungkan dengan jin yang dapat dimintai bantuan dengan menuliskan namanya, baik dalam bentuk huruf atau bilangan. Fungsinya untuk tujuan kebaikan atau kejahatan seperti menghilangkan rasa 
sakit, membuat diri tidak terlihat oleh orang lain, sehingga sering diukirkan pada bendabenda magis seperti permata, lempengan logam atau cincin yang dipakai sebagai azimat (Macdonald 1993, 770-1). Bahkan kata buduh oleh sebagian orang dipandang sebagai memiliki kekuatan (word of power) yang berasal dari Nabi Adam (Shaw 1973, 43).

\section{PENUTUP}

Dari paparan di atas dapat diambil kesimpulan bahwa fungsi bendera Macan Ali, tidak hanya sebagai lambang identitas, simbol atau jati diri kesultanan Cirebon sebagai "kerajaan bercorak Islam", tetapi ada kemungkinan bendera ini dipandang sebagai benda regalia yang memiliki kekuatan magis yang dapat mendatangkan keselamatan atau kebaikan bagi seseorang atau masyarakat, seperti halnya bendera pusaka keraton Yogyakarta Hadiningrat, Kiyai Tunggul Wulung, dan Kiyai Pare Anom. Kesimpulan itu dikaitkan dengan kehadiran gambar atau lukisan pedang zulfakar, yaitu segi empat bertuah (magic square) dengan huruf-huruf magisnya (sylable magic). Dengan demikian pada hemat penulis, terdapat kesejajaran fungsi dan makna antara gambar dan teks pada bendera yang bersangkutan.

Selain pada bendera Macan Ali koleksi Museum Tekstil, kotak-kotak magis ditemukan pada bendera Kerajaan Aceh yang dirampas oleh Belanda pada tahun 1840 dan pada bendera Eja E dari Kerajaan Bone. Dalam bahasa Bugis kotak-kotak magis itu disebut "koetika" (Matthes 1872, 11-42; Le Roux 1930, 262). Di dalam kotak-kotak segi empat yang jumlahnya 100 buah itu $(10 \times 10)$ tertulis nama-nama Allah atau "Asmaa ulhusna", dengan huruf Arab (Juynboll 1873; Le Roux 1930, 263) yang pada hemat penulis berfungsi sebagai huruf-huruf atau kata-kata magis.

Gambar binatang atau mahluk bernyawa pada bendera ditemukan juga pada dua buah bendera kerajaan Bone (Sulawesi Selatan), yaitu bendera Garuda E dan bendera Ulabulu atau Ula Balo E. Pada bendera Garuda E terdapat gambar makhluk berbadan manusia, berparuh, bersayap, dan bercakar seperti burung (manusia-burung) dalam posisi berdiri. Menurut Le Roux, makhluk hibrid itu adalah garuda yang mirip dengan penggambaran garuda pada Candi Sukuh (Le Roux 1930, 261). Kedua tangannya memegang ular, sedangkan pada keempat sudut bendera terdapat gambar singa. Singa yang di sudut kiri-kanan atas digambarkan berdiri di atas keempat kakinya, posisi kepala agak menunduk, sehingga bobot badan cenderung ke depan. Sebaliknya singa yang di sudut kiri-kanan bawah, berdiri di atas kedua kaki belakang, kedua kaki depan diangkat satu di atas yang lain, posisi kepala diangkat dan menoleh ke samping sehingga berhadapan dengan pengamat. Pada bendera Ulabulu atau Ula BaloE terdapat gambar seorang tokoh menunggang makhluk berbadan kuda, bersayap, kakinya bercakar seperti ayam, sedangkan mulutnya seperti mulut naga. Tokoh tersebut memakai mahkota dan memegang tombak. Bendera ini terbuat dari kain katun berwarna merah dengan bingkai warna coklat. Pada bingkainya terdapat tulisan Arab Lā ilāha illa Allah, Muhammad Rasul Allah (Le Roux 1930, 268). 


\section{DAFTAR BACAAN}

Al Ahmadi, Abdurahman. "General Introduction on the Cultural Development Malaysia", Arts, The Islamic World, vol. 5, No. I, 1988: 40-43 dan 96. 1988.

Anonim. "Flags of the Malay Peninsula", Journal of the Straits Branch of Royal Asiatic Society, April No. 75, 1917: 1-10. 1917.

Arnold, Sir Thomas W. "Symbolism and Islam", The Burlington Magazine 55 (JulyDecember) 1928: 155-156. 1928.

Badruzzaman, Abdul (penerjemah). Wasiat Terbesar Sang Guru Besar, Asy Syaikh Abdul Qadir al-Jailani. Jakarta: Sahara Publishers. 2004.

Bennett, James. 'Islamic Art and Civilisation in Southeast Asia", dalam James Bennett (Ed.), Crescent Moon, Islamic Art and Civilisation. Adeleide: Art Gallery of South Australia:18-101. 2005.

Gallop, Annabel The. "Islamic Manuscript Art of Southeast Asia" dalam James Bennett, Crescent Moon, Islamic Art E Civilisation in Southeast Asia. Adeleide: Art Gallery of South Australia- Adeleide, Canberra: National Gallery of Australia-Canberra: 158183. 2005.

Juynbool, A.W.T. “Een Atjinesche vlag met Arabische opschriften”, TNI, 2 (2), 1873: $325-340$.

Kusen, Sumijati AS, Inajati AR. "Agama dan Kepercayaan Masyarakat Majapahit", dalam Sartono Kartodirdjo dkk. (Ed.), 700 Tahun Majapahit (1293-1993): Suatu Bunga Rampai. Surabaya: Tiga Dara. 91-115. 1993.

Le Roux, CCFM, “De Rijksvlagen van Bone”, TBG, LXX, 1930: 205-266.

Macdonald, Duncan B. "Buduh", dalam M. Th. Houtsma (Ed.) First Encyclopaedia of Islam 1913 - 1936. Vol. II. Leiden-New York-Koln, E.J. Bril: 770-771. 1993.

Mahdihassan, S. "The Sacred Names of Allah, Muhammad and Ali, Calligraphically Inscribed to Decorate Persian Architecture", dalam Hamdard Islamicus, Vol. XI (2) : $81-$ 88. 1988.

-. "The Sacred Names of Allah, Muhammad and Ali, as Expressed in Persian Calligraphy As Art" dalam Hamdard Islamicus, Vol. XI (2), 1988: 89-95. 1988.

Mahmood, Shaukat. "Epigraphy in Pakistan Masques", Hamdard Islamicus, Vol. VIII (2), $1985: 71-89.1985$.

Mardiana, Intan dkk. Pameran Perkembangan Aksara di Indonesia. Jakarta: Museum Nasional. 2002.

Matthes, B.F. "Makassarsche en Boeginesche Koetika," TBG XVII: 1-42. 1872.

Montana, Suwedi, "Mode Hiasan Matahari pada Pemakaman Islam Kuno di Beberapa tempat di Jawa dan Madura", Makalah pada Pertemuan Ilmiah Arkeologi (PIA) III di Ciloto, 23-28 Mei 1983. Jakarta: Proyek Penelitian Purbakala Depdikbud: 722-738. 1985. 
Pijper, G.F. Beberapa Studi tentang Sejarah Islam di Indonesia 1900-1950. Penerjemah: Tujimah, Yessy Augusdi. Jakarta: UI-Press. 1984.

Ramadlan, Ust. Abu H. F. Tarjamah Duratun Nasihin. Surabaya: Penerbit Mahkota. 1987.

Ruhl, D. "Vlag en Wapen van de Republiek Indonesia", Indonesie vierde jrg. 19501951: 97-105. 1950-1951.

Safadi, Yusin Ahmad. Islamic Calligraphy. Thames and Hudson. 1978.

Shaw, William. "Miscellaneous Notes on Malaysian Magic', Federation Museums Journals Vol. XVIII: 3-57. 1973.

Schimmel, Annemarie. Caligraphy and Islamic Culture. London: I. B. Trances \& Colten Publisher. 1990. Rahasia Wajah Suci Ilahi, Memahami Islam Secara Fenomenologis.

Bandung: Mizan. 1997.

Taylor, W. R. "An Arabic Amulet," The Moslem World Vol. XXIV July (3): 161-165. 1935.

Thahir Badri, Moehammad. Syarah Kitab Al-Tauhid Muhammad Bin Abdul Wahab. Jakarta: Pustaka Panjimas. 1984.

Tirtokoesoema, R. Soedjana. "De Ommegang met den Kandjeng Kjahi Toenggoel Woeloeng te Jogyakarta Donderdag-Vrijdag 21/22 Januari 1932 (Djoemoeah-kliwon 13 Poso Dje 1862), Djawa: 41-48. 1932.

Wildan, Dadan. Sunan Gunung Jati (Antara Fiksi dan Fakta), Pembumian Islam dengan Pendekatan Struktural dan Kultural. Bandung: Humaniora Utama Press. 2002.

Zafar Iqbal, Muhammad. Kafilah Budaya, Pengaruh Persia Terhadap Kebudayaan Indonesia. Jakarta: Citra. 2006.

Zwemer, S.W. "The Swoord of Muhammad and Ali", The Moslem World Vol. XXI April (11): 109-121. 1931. . "A Chinese Arabic Amulet", The Moslem World Vol. XXV July (3): 217-222. 1935. 


\section{LAMPIRAN}

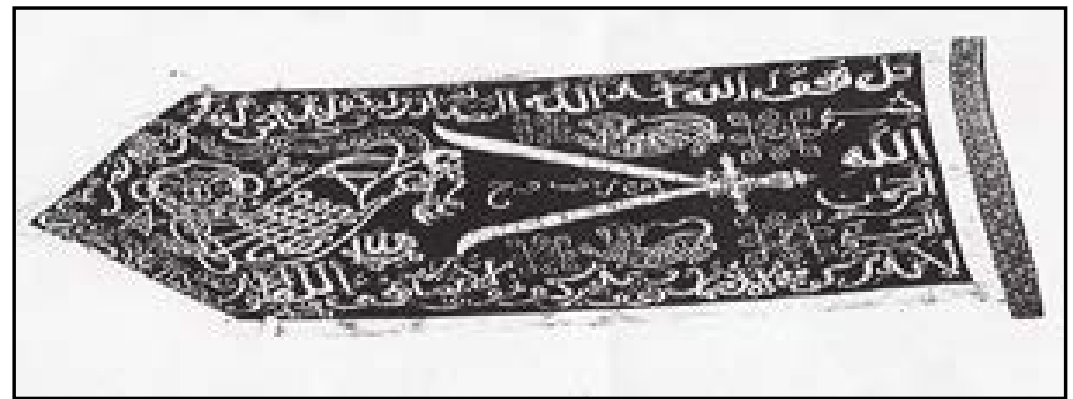

Gambar 1. Bendera Macan Ali koleksi Museum Tekstil Jakarta.

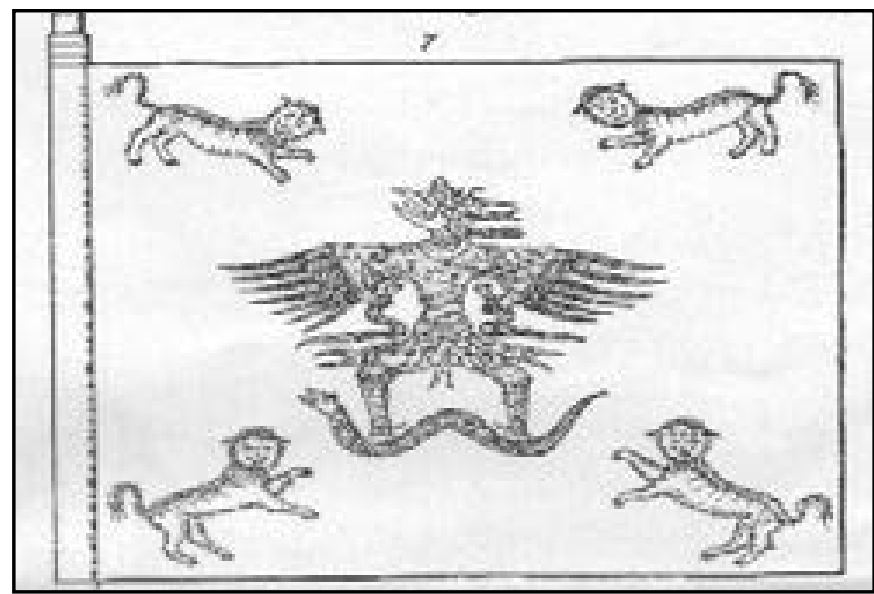

Gambar 2. Bendera Garuda E, dari Kerajaan Bone. 


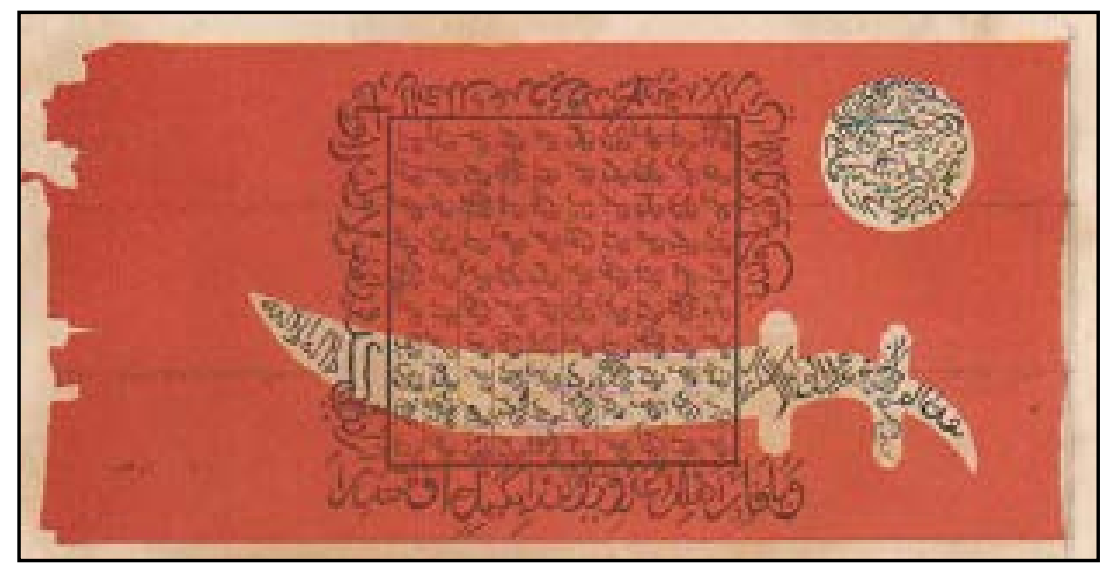

Gambar 3. Bendera Ulabulu/Ula Balo E dari Kerajaan Bone.

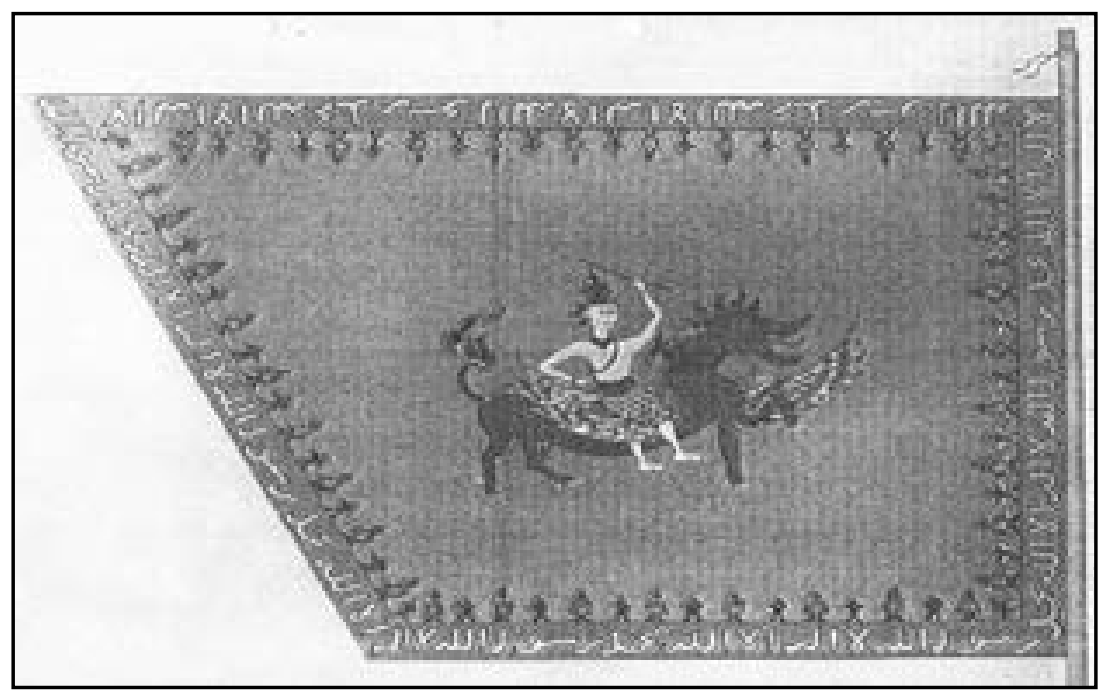

Gambar 4. Bendera Kerajaan Aceh yang dirampas Belanda tahun 1840. 